\title{
Derision and Demography: New South Wales and the Irish Orphan Girls of the Earl Grey Immigration Scheme, 1848 to 1850 \\ Benjamin McHutchion
}

From 1848 to 1850,4175 female orphans from Irish workhouses were sent to the Australian colonies to escape from the Irish famine and to address the gender imbalance in the colonies. Anglo-centric colonial newspapers condemned the girls for their supposedly inferior demographics ï Catholic, illiterate, Irish and female $\ddot{i}$ and raised the spectre of Catholic predominance, leading to the cancellation of the immigration scheme at a time of great humanitarian need. Using the original shipping lists of the girls who landed in New South Wales and the colonyôs census data, this paper uses a quantitative analysis to argue that while newspapers were relatively correct in characterizing the girlsôdemographics, they were incorrect in their claims about how the girlsôarrival would influence the colonyôs demographic development.

On the 26 of August 2010 broadcast of the Australian Broadcasting Corporationô radio program Life Matters, presenter Richard Aedy chided viewers. Amid the often harsh ñstop the boatsòrhetoric espoused in contemporary Australian debate over unsanctioned refugees arriving by boat, he wanted them to remember that the Australian population is, by vast majority, ñfundamentally a nation of boat people. ${ }^{1}$ Aedyô reflection was occasioned by the subject of the broadcast: the upcoming opening of the Irish Famine Memorial at the Hyde Park Barracks in Sydney, commemorating the 160th anniversary of the premature end of the so-called Earl Grey Scheme. This immigration scheme oversaw the arrival of a total of 4175 Irish orphan workhouse girls in the Australian colonies between 1848 and $1850 .^{2}$

The arrival of the orphan girls makes a fascinating case study in Australian history, and shows how many of the same processes that occurred in the early British settlement of the country were still being repeated in the mid-nineteenth century. This paper demonstrates that the Irish orphan girls were at a distinct disadvantage, due to their supposed personal characteristics, which were subject to much discrimination, and because of the specific time period in which they arrived in Australia. This discrimination stemmed from long-term prejudices rooted in the unique historical context of the Australian colonies and in the dominant English culture, and in a conflict between the Australian colonists and the British government over the possible resumption of convict transport. This paper goes on to investigate two related questions through quantitative analysis. First, how close were the Irish orphan girls to their portrayal in the Australian newspaper media of 1848 to 1850 , which talked of them as overwhelmingly poor, Roman Catholic and unintellectual? The shipping lists of the girls who landed in Sydney will be

\footnotetext{
${ }^{1}$ Australian Broadcasting Corporation, ñThe Irish Famine Orphan Girls, ò Life Matters, August 26, 2010. Accessed March 28, 2014.

${ }^{2}$ Patrick OâFarrell, The Irish in Australia: 1788 to the Present (Sydney: University of New South Wales Press Ltd., 2000), 74.
} 
used to answer this question. Second, how did these girls fit into and affect the wider demographic picture of New South Wales? More specifically, did the Australianôs fear of being overwhelmed by Catholics, prompted by stories in the Australian newspapers, ever materialize? The census records of New South Wales will be used to assess how the girlsôarrival affected the demographics of the colonial population, looking specifically at how the girls compared to and potentially affected the population they were joining in terms of religion, literacy and national origin.

While focused on Australia, this paper is also pertinent to Irish historiography, as it examines the colonial discourse of the English-Irish relationship during the period of the Great Famine. The tenacity of this discourse in the English mindset is revealed by its reappearance, essentially unmodified, in Australia. It also provides evidence of the disadvantaged position of Catholics in Ireland, seen in the lower levels of literacy of Catholic compared to Protestant orphans. This paper may do a small part to answer the call of certain Irish postcolonial historians for ñrish studies [to] do away with its isolationismé in order to see itself relationally with other cultures and nationsò by considering the Irish experience in the Antipodean context. ${ }^{3}$

To fully understand the nature of the orphan girlsôjourney, one should understand the situation in Ireland that led the girls to enter workhouses, and then to be sent overseas. The potato fungus Phytophthora infestans first struck Ireland in 1845, and lasted until 1850 , devastating the potato crops upon which most of Irelandôs poor had been dependant for their daily sustenance. The resulting Great Famine caused profound hardship, leading to the deaths of about 1.5 million Irish, and the emigration of one million more. ${ }^{4}$ One response of the British Government to this crisis was to put impoverished, hungry people, many of them children, into workhouses. Conditions and mortality rates inside the workhouses were so terrible that many people chose to suffer on the outside rather than enter these institutions. By 1847, there were 120000 people, including 55000 children under 15 years of age, in Irish workhouses. ${ }^{5}$ Some of these children were truly orphans, while others entered the workhouse when their parents emigrated, with the hope that their parents would eventually regain custody of them in the future. ${ }^{6}$ Not all the so-called orphan girls were actually orphans, but upon their entry into a workhouse, the authority of their parents was replaced with that of the state.

Meanwhile, in New South Wales, the administration of Governor Sir Charles Fitzroy was under pressure to provide more females in the colony, both to help address a shortage in domestic servants and to help counter the demographic imbalance between the sexes that had persisted since convict transportation had begun. In the 1840s, there were still areas in the interior of Australia that were as high as 83 per cent male. ${ }^{7}$ This need was

\footnotetext{
${ }^{3}$ Catriona Moloney and Helen Thompson, ñIntroduction: óBorder Traffic, ஸ̂̀ Journal of Commonwealth and Postcolonial Studies, 7.1 (2000): 4.

${ }^{4}$ Thomas William Heyck, The Peoples of the British Isles: A New History From 1688 to 1870, Belmont, California: Wadsworth (1992), 334-335.

${ }^{5}$ Joseph Robins, ñIrish Orphan Emigration to Australia 1848-1850,ò An Irish Quarterly Review 57 (1968): 374.

${ }^{6}$ Robins, Irish Orphan, 373-374.

${ }^{7}$ Robins, Irish Orphan, 373.
} 
communicated to the British government. Earl Grey, Secretary of State for the Colonies, responded to this request by conceiving of an immigration scheme for the colonies. In 1847, he reported back to Australia with plans to send 5000 adults. ${ }^{8}$ The scheme was also advantageous from the perspective of the British government, as a way to relieve the workhouse overcrowding in Ireland resulting from the overwhelming need created by the famine. As had happened in the earliest decision to colonize Australia in 1788 due in large part to overcrowded ñgaols, ò the crowding of government institutions, workhouses in this instance, became a motivating factor for the government to back an immigration scheme. ${ }^{9}$

It would seem that Britain and the Australian colonies should have been pleased with this arrangement, with both sides benefitting and an overwhelming humanitarian cause being served. But this was not to be. Opposition from the Australian public ended the orphan girl scheme early, after only two years. Concerns with this scheme quickly arose in Australia for a variety of reasons. Anglican and Presbyterian Australians, who had come from Ireland originally, instigated much of the opposition based on sectarian concerns. They aided transplanting sectarian tensions from Ireland into the colonial community. ${ }^{10}$ These Protestant Australian colonists opposed the orphans in part due to three distinct aspects of their identity, which compounded to make the girls especially vulnerable to the majoritarian prejudices of the Australian colonies. The girls were Irish, they were paupers, and perhaps most condemnable, they were Roman Catholic.

Another aspect of the opposition to the girls centered on long-held beliefs among the English colonists in their own racial superiority. The English migrants to Australia had taken with them a sense of superiority based in the Imperial success and technological advances led by England in the Victorian era. This superiority manifested itself in opposition to other groups, including Catholics and those fleeing from ñstarving Ireland. ${ }^{11}$ An entry defending the girls in the Geelong Advisor of 13 May 1850, lays the basis for the derision of the girls squarely on their ethnicity, saying ñthey are calumniated only because they are Irish, and of the right sort; were they English, Scotch,

Greenlanders, or Esquimaux, they would not have been objected to, and barred, denounced, and refused what any savage would have received at the hands of a Christian. ò $^{12}$

Australians had a firmly established tradition of deriding the immigrants sent from Britain as undesirables. In this instance, the orphans were called the ñworkhouse sweepingsò of the Empire and the scheme equated with r̃being inundated with Irish

\footnotetext{
${ }^{8}$ Ibid.

${ }^{9}$ A.G.L. Shaw, ñThe Beginning of Transportation to Australia,ò in Convicts \& The Colonies: A Study of Penal Transportation from Great Britain \& Ireland to Australia \& other parts of the British Empire (Melbourne: Melbourne University Press, 1998): 44.

${ }^{10}$ Robins, Irish Orphan, 378-79.

${ }^{11}$ James Jupp, The English in Australia (Cambridge: Cambridge University Press, 2004), 33.

12 ñrish Orphan Immigration,ò Geelong Advertiser, May 13 1850. Morning edition, 2. Retrieved March 15, 2014, http://nla.gov.au/nla.news-article93137443.
} 
paupers. ${ }^{13}$ This tradition had developed due to the transportation of convicts to the colonies in the past, as well as the development of a stigma of unworthiness around the concept of the ñassistedò immigrant. In actual fact, most assisted immigrants to Australia were not socially destitute but were rather well educated and possessed skills needed in the colonial economy. ${ }^{14}$ Despite this, the myth was a powerful one. The Irish workhouse girls were an exception to the established rule that those within the workhouses were ineligible to receive government assistance with their passage. ${ }^{15}$ When the Irish girls were sent out from the workhouses, truly some of the most desperate of Irelandôs poor in a desperate period of Irish history, this reflexive derision found a target that was all the more powerful because it was, in this case, true. In spite of the human disaster transpiring in Ireland, the rate of assistance for Irish immigration during the famine period actually fell. In the 1845 to 1852 period, only 1 per cent of immigrants received assistance, compared with 3.2 per cent in the years 1815 to 1845 . $^{16}$

One exceptionally blunt article in the Argus newspaper of Melbourne, dated 24 January 1850 , demonstrates the very low view of the orphan girls, both in their intellectual abilities and physical characteristics. It also presents yet another critique of the scheme $\ddot{i}$ that the scheme was favouring Irish girls at the expense of the other (implicitly superior) cultural groups of the British Isles. In suggesting that other British ethnic groups be encouraged to emigrate instead, the writer is obviously ignoring the desperate situation faced by so many in Ireland at the time. The anonymous editorial tells us that the Irish orphans were:

A set of ignorant creatures, whose whole knowledge of household duty barely reaches to distinguishing the inside from the outside of a potato, and whose chief employment hitherto, has consisted of some such intellectual occupation as occasionally trotting across a bog to fetch back a runaway pig. Our money ought to be expended upon the rosy cheeked girls of Englandé upon the braw lasses of bonnie Scotland, or upon the better description of the bright-eyed daughters of Erin, instead of being wasted upon these coarse, useless creatures, whose very personnel, with their squat, stunted figures, thick waists, and clumsy ankles, promises but badly for the physique of the future colonists of Victoria[.] ${ }^{17}$

The mention of a runaway pig is not an accidental choice of farm animal. The pig was a central part of the English colonial discourses used to describe the backwardness of the Irish. To the English imagination of the mid-1800s, Ireland was a land where the human

\footnotetext{
${ }^{13}$ ñGlorious Prospects for South Australia,ò South Australian Register (Adelaide), February 26,1850, accessed March 23, 2014, http://nla.gov.au/nla.news-article38450353 and Trevor McClaughlin, ñLost Children? Irish Famine Orphans in Australia,ò in History Ireland 8 (2000): 30.

${ }^{14}$ Robin Haines, ñThe Idle and the drunken wonâ do thereô Poverty, the New Poor Law and Nineteenthcentury Government-assisted Emigration to Australia from the United Kingdomòin Australian Historical Studies 108 (1997): 3.

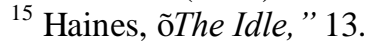

${ }^{16}$ Trevor Parkhill, ñWith a little help from their friends: assisted emigration schemes 1700-1845,ò in To and From Ireland: Planned Migration Schemes c. 1600 - 2000, edited by Patrick J. Duffy (Dublin: Geography Publications, 2004): 78.

17 ñFemale Orphan Immigration,ò The Argus (Melbourne), January 24, 1850, 2, accessed March 24, 2014, http://nla.gov.au/nla.news-article4771328.
} 
and porcine inhabitants lived in close domestic contact. Irish immigrants supposedly brought a traditional filth and stench with them even when they moved into English slums. So strong was this folklore that the pig became a symbol of the Irish, of an uncivilised baseness and squalor that led some to wonder in jest whether the Irish shared a common lineage with their ubiquitous household pigs. ${ }^{18}$ As another contemporary example, one may turn to the words of the Scottish philosopher Thomas Carlyle. He makes mention of pigs, and paints the Irish as subhuman, calling them ñthe sorest evil this country has to strive withé he lodges in any pig hutch or dog hutch, roosts in outhouses.... The Saxon man may be ignorant, but he has not sunk from decent manhood to squalid apehood. ' $^{19}$

Some Australians were also afraid of being overwhelmed by young Catholics, and of their potential to give birth to a new multitude of Catholic children. Sectarian opposition to Catholicism raged through the newspapers, including the anonymous writer in the Argus:

These girls are, we believe, exclusively Roman Catholicé [they] will naturally wed with our shepherds, hutkeepers, stockmen, etc. who, as a body, we blush to say, are little better than heathensé if the children have any religion at all, they will be Roman Catholics to an individual; the mother will dictate the religion of the familyé we should look with very deep grief and dread upon the probability of the majority of our community ever being composed of Roman Catholicsé that religion is unfavourable to the development of liberty, of safety, of public happiness or progressé the slightest reference to Spain, Italy, Portugal, or any other country where Catholicism flourishes uncheckedé is more conclusive than a volume of discussion could be. ${ }^{20}$

It is worth mentioning the significance of the time period of the Earl Grey scheme in relation to the experiences of Catholics in Britain. The Catholic hierarchy was reestablished in the British Isles in 1850, setting off waves of anti-papist protest and vitriol, including thousands of petitions and ñseven thousand meetingsò around Britain. It is quite possible that some of the harshness of the orphan critiques may stem from a reassertion of anti-Catholicism in the face of this ñpapal aggression. ${ }^{21}$ Indeed, the stigmas of Irishness and Catholicism had become closely associated as hundreds of thousands of Irish poor entered England in the decades before 1850, increasing the Catholic population of England perhaps twenty times from its size in $1800 .^{22}$ There also existed a longstanding claim that Catholicism could not coexist with the English political order, as it was asserted that the ultimate loyalty of a Catholic had to be to the will of the papacy

\footnotetext{
${ }^{18}$ Joseph Nugent, ñThe Human Snout: Pigs, Priests, and Peasants in the Parlour,ò Senses and Society 4:3 (2009): 288.

${ }^{19}$ Walter Ralls, ñThe Papal Aggression of 1850: A Study in Victorian Anti-Catholicism,ò Church History 43:2 (Jun., 1974), 244.

${ }^{20}$ ñFemale Orphan Immigration,ò The Argus (Melbourne), January 24, 1850, 2, accessed March 24, 2014, http://nla.gov.au/nla.news-article4771328.

${ }^{21}$ Ralls, ñThe Papal Aggression,ò 243.

${ }^{22}$ Ralls, ñThe Papal Aggression,ò 244.
} 
and not to England. Catholics were therefore supposedly more liable to become traitors. ${ }^{23}$

Political opposition was also aroused by the immigration scheme, based on a distrust of Earl Grey in the Australian colonies, who was at this time considering the resumption of convict transports. ${ }^{24}$ The Order in Council of 1840 that had ended transportation to New South Wales was revoked, and a new Order in Council of 4 September 1848 had named New South Wales, Van Diemenôs Land and Norfolk Island, in addition to the Cape Colony, as potential destinations for transportation to begin anew. ${ }^{25}$ Hatred of this potential reversal in convict policy meant that any scheme conceived by the Earl lacked the ñadvantage of coming from an esteemed source. $0^{26}$ That the scheme was associated with Earl Grey therefore made it a target for Greyô detractors.

The 1840s were the beginning of a period of important changes in the relationship between the Australian colonies and Imperial Britain, culminating in Australiaôs Federation in 1901. ${ }^{27}$ The threat of the resumption of convict transports created a huge amount of resentment and a feeling of ñbad faithò shown by London to the colonies. The colonistsôopposition to convict transports can be seen as the beginning of the various Australian colonies realizing the potential benefits of becoming a united front. ${ }^{28}$ The orphan girls were caught up in issues of colonial resentment. This was also brought to the fore by the financial stake the Australian colonies had in bringing the girls to Australia, while being relatively powerless to influence the immigrants the British officials chose to send. The revenues from the sale of Crown Land in the Australian colonies had been used to fund immigration since $1831 .^{29}$ Australian money was being used to finance the girlsôimmigration, and therefore the Australians felt they were entitled to expect the very best sort of immigrant their money could obtain. The writer in the Argus began with this concern, saying:

[If] the British Government took upon itself the cost é we might look over some of the objectionable qualities of the strangers; and our desire to see the proper balance between the sexes maintained, would go a great way in inducing us to submit to the continuance of the arrival of these girls. But spending our own money, unadded to and unaided, we have a right to expect the very best class of immigrants that can be induced to venture to this happy land, and it is down-right robbery to withhold our funds from decent, eligible, well-brought-up girls, who would make good servants to-day, and virtuous, intelligent wives tomorrow[.] ${ }^{30}$

\footnotetext{
23 Ibid.

${ }^{24}$ McClaughlin, Lost Children, 30.

25 John M. Ward, Earl Grey and the Australian Colonies 1846-1857: A Study of Self-Government and Self-interest (Melbourne: Melbourne University Press, 1958): 196.

${ }^{26}$ Ward, 119-120.

${ }^{27}$ Lindsay Proudfoot and Dianne Hall, Imperial Spaces: Placing the Irish and Scots in Colonial Australia (Manchester: Manchester University Press, 2011): 4.

${ }^{28}$ Ward, Earl Grey, 119.

${ }^{29}$ Haines, ñThe Idle, " 7.

${ }^{30}$ ñFemale Orphan Immigration,ò The Argus (Melbourne), January 24, 1850, 2, accessed March 24, 2014, http://nla.gov.au/nla.news-article4771328.
} 
One final aspect that made the girls vulnerable was their gender. As single women travelling alone with little supervision, their character and conduct were called into question. Once again, a long-standing and false association led to discrimination against these girls. From early in Australian history, female migrants, especially convict women, had been associated with prostitution, leading to what has been termed the ñdamned whoreò stereotype. ${ }^{31}$ This tradition supposed that a single female travelling without protection of a family, either of a father, a male relative or a spouse, was to be seen as potentially immoral. ${ }^{32}$ The legacy of this earlier stereotype, or at the least the dim view taken of single female migrants, can be seen in the Irish girlsôreception. Indeed, immediately upon the arrival of the first ship, the Earl Grey, the Surgeon-Superintendent in charge of the girls reported that they were not orphans but rather ñprostitutes and beggars. O $^{33}$ This seems unlikely, as the selection process had been very strict. ${ }^{34}$ One newspaper article placed eight dash marks in order to redact the names of girls who were supposedly known as prostitutes in Belfast. ${ }^{35}$ The Goulburn Herald of 16 March 1850 declared that immigration officials found many Irish girls working as prostitutes in Adelaide, but goes on to charitably say they did not ñcondemn the whole of these girls as prostitutes, but those who are noté [are still] worthless as servants. o $^{36}$ As late as 1855, the New South Wales agent for immigration commented on ñthe uselessness of the majority of the single females. $0^{37}$ This slander of worthlessness, as evidenced in the newspaper articles, stemmed from their alleged deficiency in intellect, their inexperience with housework, and even a racial inferiority apparent when compared to other ethnic groups of the British Isles. We see two options for the girls expressed in these attacks on their character: they are either prostitutes, or otherwise worthless to the colony.

Before moving on to the quantitative portion of the paper, it is worth noting that the criticism in newspapers may not have reflected the reality of opinion in the colony. In the township of Yass, for example, the residents were extremely positive in their assessment of the girls, even going so far as to have a petition declaring their satisfaction signed by 48 ñleading residentsò of the community. ${ }^{38}$ Even in the case of the Earl Grey orphans, who had been slandered as prostitutes and beggars, many had no trouble finding employment and were quickly hired. ${ }^{39}$

Was the characterization of the orphans by the Australians in the Australian newspapers as Catholic and ignorant correct? To investigate this question, the demographic information reported by the orphan girls will be examined. This information is available

\footnotetext{
${ }^{31}$ Portia Robinson, ñ am not for Marrying,ò in The Hatch and Brood of time: A Study of the First Generation of Native-born White Australians (Melbourne: Melbourne University Press, 1985): 66.

${ }^{32}$ Robinson, 73.

${ }^{33}$ Robins, Irish Orphan, 379-380.

${ }^{34}$ Haines, ñThe Idle, " 13.

35 ñWorkhouse Emigration, ò The Sydney Morning Herald, August 19, 1850, accessed April 3, 2014, http://nla.gov.au/nla.news-article12920366.

${ }^{36}$ ñrish Orphan Immigration,ò The Goulburn Herald, March 16 1850, http://nla.gov.au/nla.newsarticle101728899.

${ }^{37}$ Jupp, The English in Australia, 70.

${ }^{38}$ Michael Campbell, Ireland's New Worlds: Immigrants, Politics, and Society in the United States and Australia, 1815-1922. (Madison, Wisconsin. University of Wisconsin Press, 2008), 58-59.

${ }^{39}$ Robins, Irish Orphan, 380.
} 
from the shipping lists of the eleven orphan ships that landed in Sydney over the schemeôs duration. These ships, in order of their arrival, were the Earl Grey, Inchinnan, Digby, Lady Peel, William and Mary, Lismoyne, Panama, Thomas Arbuthnot, John Knox, Maria, and the Tippoo Saib. In terms of time range, the Earl Grey arrived on 6 October 1848, and the Tippoo Saib landed 30 July $1850 .^{40}$ These eleven ships carried a total of 2240 female orphans. ${ }^{41}$ For an idea of how Sydney compared to the other ports of arrival, 1255 orphans arrived in Port Philip (Melbourne), and 606 in Adelaide. ${ }^{42}$

There is no way to put a quantitative value on a concept like ignorance in a value neutral manner. It is a concept that depends very much on the cultural context, and is an individual value judgement. Instead, literacy will be used as a proxy, as a way to examine the trait of being ñunintellectual,ò which was another word used to describe the girls by many Australian newspapers. What literacy can show is a personô access to education. Three categories of ñintellectualò ability were recorded on the shipping lists. These were: Read, Both (can read and write), and Neither. While there are stages and abilities of literacy that fall between these, the categories are useful in that they provide clear groupings that can be counted and evaluated.

When looking at the girlsôliteracy, 41 per cent could neither read nor write, 32 per cent could read only, and 27 per cent could do both. But this hides a disparity, where the rates of literacy depend heavily on the religious background of the girl. Forty-one per cent of the Protestants (Anglicans, Presbyterians, and two sisters aboard the Inchinnan who only declared themselves Protestant) could read and write, but only 24 per cent of the Roman Catholic girls could do so. Forty-five per cent of Catholics could not read or write, while only 17 per cent of Protestants could not. Forty-two per cent of Protestants could read, as could 31 per cent of the Catholics. It is worth noting how, so far from home, the cross section of Irish society seen in the example of the Irish girls can still show the effects of the advantaged position Protestants had over the Catholics in Ireland.

When compared to the adult female population of New South Wales, the Irish girls reported lower rates of literacy. In 1846, the reported literacy rates for New South Wales females over age 21 years was: both 54, neither 25 , and read only 21 per cent. In 1851 , the result was: both 59, neither 21 , and read only 20 per cent. We therefore see that the Irish Catholic girls had a much higher rate of illiteracy compared to the women of New South Wales. The Irish Protestant girls had a slightly lower proportion of those unable to read or write, but also had a significantly lower proportion who were fully literate. They also had a significantly higher proportion of those who could only read. The contention in the newspapers that the girls appeared unintellectual may have been based in part due to the differing rates of literacy between the Irish girls and the adult female colonists.

\footnotetext{
${ }^{40}$ Irish Famine Memorial, ñFamine Orphan Girl Ships to Australia,ò accessed March 28, 2014. http://www.irishfaminememorial.org/en/orphans/ships/.

${ }^{41}$ See Table 1 for the citations for all demographic data on the orphans.

${ }^{42}$ Oôfarrell, The Irish in Australia, 74.
} 


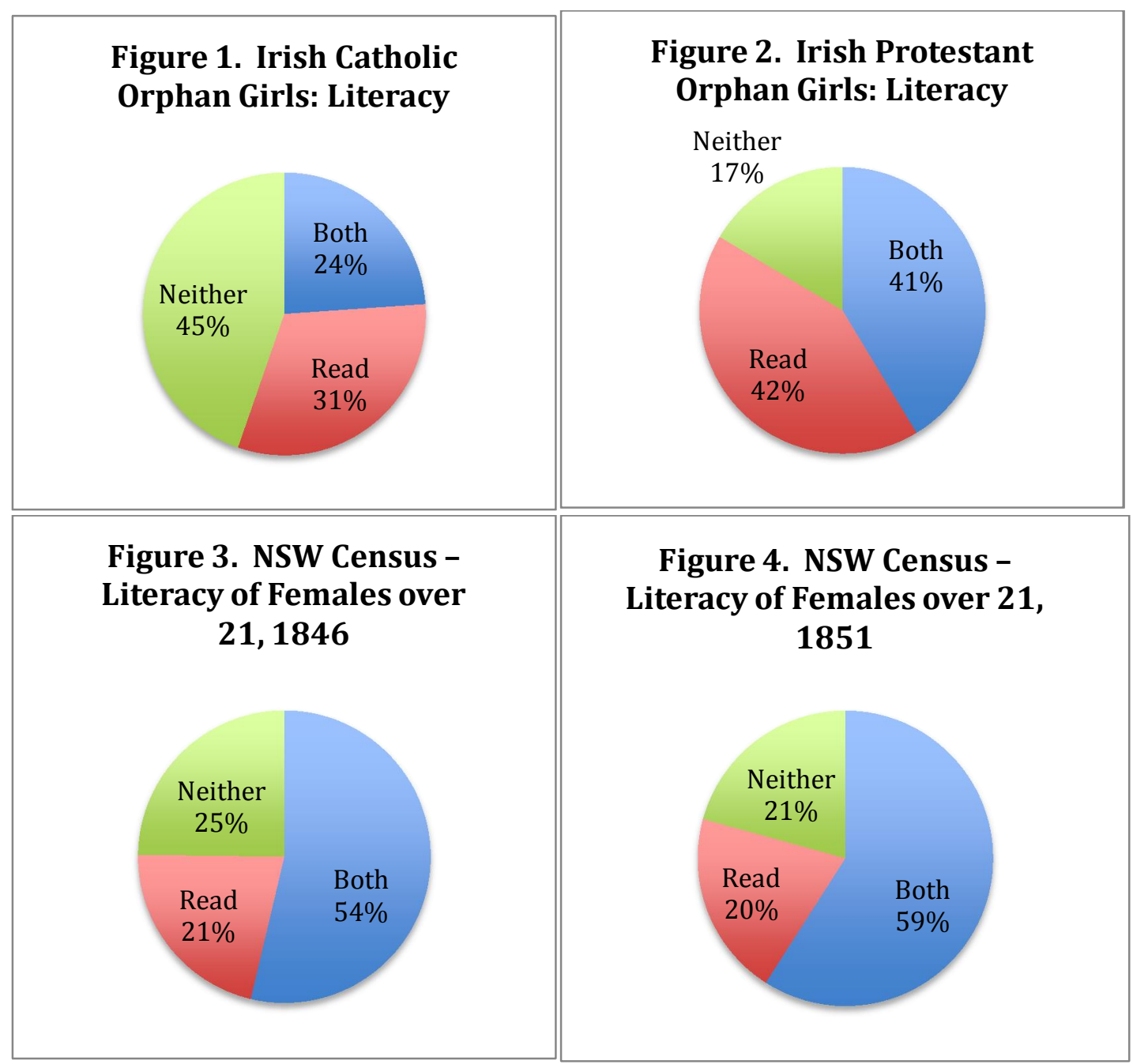

In terms of the girlsôreligious demographics, the characterizations of the newspapers were relatively accurate. The girls were 90 per cent Roman Catholic, and 9 per cent Anglican. The remaining 1 per cent of the girls were Presbyterians. Almost half the Anglicans came on the first ship, and most of these orphans came from counties in the modern Northern Ireland. This was the only ship to carry Presbyterians, and also the only ship in which Catholics were the minority.

There is a distinct possibility that the makeup of this first ship differed from the others on purpose, in order to introduce the scheme to Australian shores and to make it more acceptable by sending a majority of Protestants. There is precedent for the British government showing sensitivity for the colonistsôperceptions in this period. In the case of South Australia, it was decided by the Colonial Office that of the initial group of ships to be sent out, only one would be deployed to South Australia, as emigration officials wished to judge that colonyôs reaction to the initial group of girls before sending more. There were objections that this colony might be endangered, as it had been established 
for colonists of a higher social standing than the other colonies in Australia. ${ }^{43}$ The orphans clearly were not considered to be of this higher calibre of colonist.

In light of the girlsôoverwhelming Catholicism, did the New South Wales colonistsôfear of being swamped by Catholic immigrants come to pass? Looking at the statistical information, it becomes apparent that this threat did not materialize. Overall, the religious picture of the colony remained relatively stable. Figure 5 shows the share of different religions in the population of New South Wales in the period from 1846 to 1861. In addition, Figure 6 shows the changing total number of individual adherents to different religions in New South Wales for the same time period. ${ }^{44}$ Change between the two census years of 1846 and 1851, when the orphans arrived, was small, and Catholicism in fact shrank as a share of the population from 31 to 30 per cent. Over the longer time period of 1846 to 1861, Anglicanism dropped from 52 to 46 per cent of the population, and Catholicism from 31 to 28 per cent. Presbyterians remained stable at 10 per cent, other Protestant denominations rose from 2 to 4 per cent, and Wesleyans rose from 4 to 7 per cent. Overall, the share of those practicing a Protestant form of Christianity remained stable, hovering just below the 70 per cent mark. The major change during in this period was the rise of the ñotherò group, from almost 0 to 5 per cent. The 1856 census explicitly attributed this to the increasing numbers of Chinese immigrants arriving in Australia. ${ }^{45}$

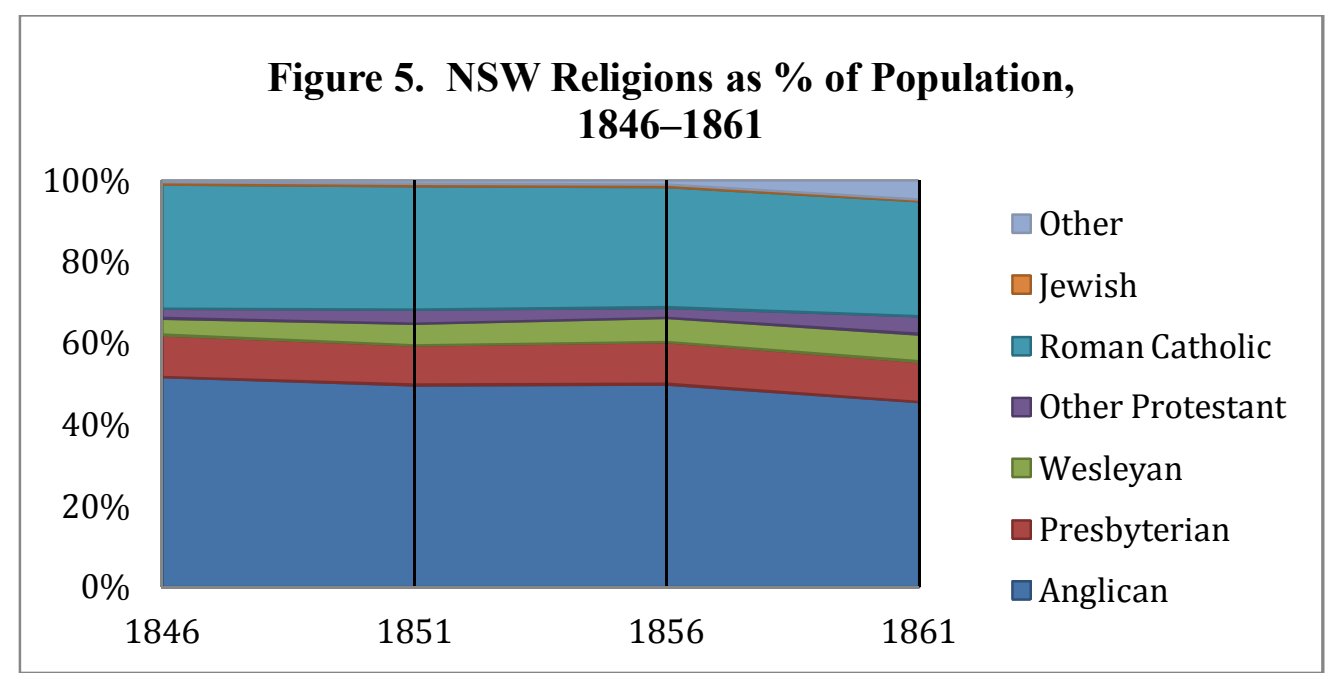

\footnotetext{
${ }^{43}$ Robins, Irish Orphan, 378.

${ }^{44}$ For raw numbers and citations used for Figures 5 and 6, see Table 3 in the Appendix.

${ }^{45}$ ñNew South Wales Census, Education, 1846,òhttp://hccda.anu.edu.au/pages/NSW-1856-census-02_xxii.
} 


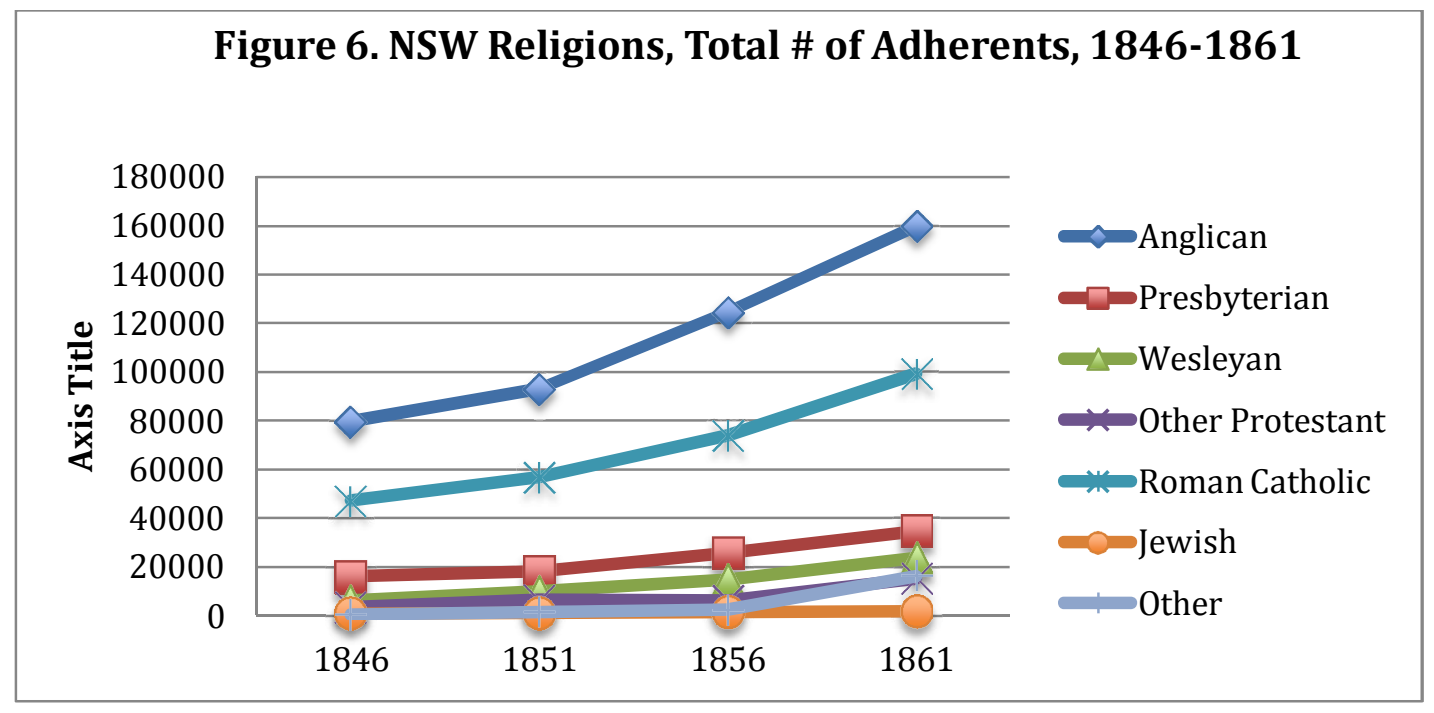

Examining Figure 6, it is clear that the total Catholic population in New South Wales was rising. However, with the context that Figure 5 provides, it is also clear that this growth was never at a rate that threatened to eclipse the Protestant majority. By focusing only on the total number of Catholics in New South Wales, rather than their relative share of the colonyô population, those decrying the orphans could ignore the wider demographic story, which demonstrated that Catholics were a decreasing proportion of the colonyôs population, far from becoming an overwhelming presence in New South Wales.

The short time period during which the thousands of girls entered the colony would have exacerbated the fear of being overwhelmed by Catholics. ${ }^{46}$ Contemporaries who were sympathetic to the scheme recognized that the large number of girls arriving in a compressed time period contributed to the concerns of the colony. They identified that the greatest mistake of the scheme was in its ñsending out so manyé in the short space of eighteen monthsò and the attendant difficulty of finding enough masters of good character to entrust with the girlsôñmoral training. ơ $^{47}$

The concern that the Catholic girls would marry Catholic men and produce Catholic families did not happen in a majority of cases. After their arrival, the Catholic girls were integrated into Protestant families. An investigation cited by historian Trevor McClaughlin looked at a sample of 280 of the girls who had landed in Port Philip (Melbourne), examining what happened to them in terms of family formation after their arrival. Of this sample, two-thirds married within three years of arriving in Australia. Fifty-six percent of the girls married Englishmen, 30 per cent married Irishmen, and most of the girls married men who did not share their religion. ${ }^{48}$ It appears that many of the orphan girls became part of Protestant, English families, and were absorbed into the dominant English culture and character of the colony.

\footnotetext{
${ }^{46}$ Oâfarrell, The Irish in Australia, 78.

${ }^{47}$ ñrish Orphan Girlsò Freeman's Journal, January 9 1851, 7. Retrieved March 15, 2014, from http://nla.gov.au/nla.news-article115767770.

${ }^{48}$ Trevor McClaughlin, ñLost Children? Irish Famine Orphans in Australia,ò History Ireland 8 (2000), 33.
} 
One final piece of evidence provided by the census answers the question of country of birth. While this question hides the national origins of all the citizens of the colony, not differentiating among those born in the colony, it does give a sense of how many new Irish arrivals were present in the colony, and especially whether the injection of 4175 Irish girls had any perceptible effect on the ethnic composition of the population. Between the 1841 and 1851 censuses, the period of the girlsôarrival, the proportion of people born in Ireland actually fell from 25 to 21 per cent. In this sense, the arriving Irish girls were in fact helping to shore up the shrinking category of the Irish-born population. The share of those born in England similarly fell, from 31 to 27 per cent. The only group that was growing significantly was those born within the colony itself, the number jumping from 35 to 44 per cent of the colonyô inhabitants. By 1851, the census reported the total population of New South Wales as 187 243, of whom 81391 were born in the colony. ${ }^{49}$ Increasingly, the colony was composed of those born within it. Those ranks would soon be swelled by the children of the orphan girls from Ireland for whom nine children was a typical number, as found in the McClaughlin study. ${ }^{50}$

Looking at the Earl Grey scheme, it is remarkable how perfectly placed the Irish orphan girls were to become the object of public resentment and ridicule in the Australian colonies. The dominant Anglo-Saxon and Protestant culture of the continent carried feelings of superiority that looked down on Catholics and the Irish. A long-held belief that Australia was not getting the highest quality of migrants from Britain, but rather paupers, was aroused by this admittedly humanitarian venture. Another persistent belief was the denigration of single female travellers, who had since the earliest convict transports, been assumed to be associated with disrespectability, and even prostitution. The orphans were therefore entering a society in which many of their characteristics were vulnerable to persistent cultural prejudices. Add to this the politicized aversion to Earl Grey, the schemeôs best known instigator, for his support for convict transportation, and the cold welcome the girls received becomes much more understandable in this context.

The quantitative analysis presented in this paper reveals information about the girls and the colony they were entering. Firstly, the girls were indeed overwhelmingly Catholic. The charges made against the girls that they were mostly Catholic appear to be supported by the self-reported demographic information they provided in the shipping lists. However, no overwhelming wave of Catholic population broke over the colony, as the census records demonstrate Catholicismôs share of the population decreased between 1846 and 1861. Secondly, the share of those born in Ireland and residing in the colony also decreased between 1846 and 1851, a time period that bookends the arrival of the orphan girls. Thirdly, that the girls were unintellectual, which is here reinterpreted as lacking in education, is somewhat but not fully supported. As a group on average, they were less literate than the adult female population of the colony. However, the overall reported rate of female literacy in the colony improved between the 1846 and 1851 census.

\footnotetext{
${ }^{49}$ See Table 2 of the Appendix.

${ }^{50}$ McClaughlin, Lost, 33.
} 
In spite of getting the demographic character of the girls relatively correct, those opposed to their immigration were mistaken as to how they would affect the colony. The distance between the feared result and the reality perhaps demonstrates an underestimation of New South Walesôability to absorb new migrants, and of the ability of those migrants to integrate into the established population. If the Irish orphan girls were in fact ñAustraliaô first boat people, ò as was asserted on Aedyô broadcast, this demonstration of the ability of prejudice, a narrow time frame, and a lack of demographic context to excite sectarianism and xenophobia against immigration may be just as relevant today as it was in the mid-nineteenth century. ${ }^{51}$

\footnotetext{
${ }^{51}$ Australian Broadcasting Corporation, ñThe Irish Famine Orphan Girls, òLife Matters, August 26, 2010.
} Accessed March 28, 2014. 


\section{Appendix}

All shipping records are available from http://www.records.nsw.gov.au/statearchives/guides-and-finding-aids/nrs-lists/nrs-5316.

All census records are available from http://hccda.anu.edu.au/documents/.

Specific web addresses for each shipping and census document are cited below.

\section{Table 1. Orphan Girls’ Demographics - Religious Identification}

(continued on next page)

\begin{tabular}{|c|c|c|c|c|}
\hline & $\underline{\text { Anglican }}$ & $\underline{\text { Presbyterian }}$ & $\underline{\text { Protestant }}$ & $\underline{\text { Catholic }}$ \\
\hline Earl Grey $^{52}$ & 80 & 31 & & 72 \\
\hline Inchinnan $^{53}$ & 8 & & 2 & 154 \\
\hline Digby $^{54}$ & 26 & & & 203 \\
\hline Lady Peel $^{55}$ & 11 & & & 155 \\
\hline William \& & & & & \\
\hline Mary $^{56}$ & 9 & & & 153 \\
\hline Lismoyne $^{57}$ & 12 & & & 154 \\
\hline Panama $^{58}$ & 7 & & & 150 \\
\hline Thomas & & & & \\
\hline Arbuthnot $^{59}$ & 4 & & & 190 \\
\hline John Knox ${ }^{60}$ & 19 & & & 260 \\
\hline Maria $^{61}$ & 3 & & & 240 \\
\hline Tippoo Saib $^{62}$ & 13 & & & 284 \\
\hline TOTALS & 192 & 31 & 2 & 2015 \\
\hline
\end{tabular}

Overall number of girls: $192+31+2+2015=2240$

\footnotetext{
${ }^{52}$ http://srwww.records.nsw.gov.au/ebook/list.asp?series=NRS5316\&item=4_4786\&ship=Earl\%20Grey

${ }^{53} \mathrm{http}: / /$ srwww.records.nsw.gov.au/ebook/list.asp?series=NRS5316\&item=4_4786\&ship=Inchinnan

${ }^{54} \mathrm{http}: / /$ srwww.records.nsw.gov.au/ebook/list.asp?series=NRS5316\&item=4_4786\&ship=Digby

${ }^{55} \mathrm{http}: / /$ srwww.records.nsw.gov.au/ebook/list.asp?series=NRS5316\&item=4_4816\&ship=Lady\%20Peel

${ }^{56} \mathrm{http}$ ///srwww.records.nsw.gov.au/ebook/list.asp?series=NRS5316\&item=4_4786\&ship=William\%20and $\% 20$ Mary

${ }^{57}$ http://srwww.records.nsw.gov.au/ebook/list.asp?series=NRS5316\&item=4_4786\&ship=Lismoyne

${ }^{58} \mathrm{http}: / /$ srwww.records.nsw.gov.au/ebook/list.asp?series=NRS5316\&item=4_4816\&ship=Panama

${ }^{59} \mathrm{http}: / /$ srwww.records.nsw.gov.au/ebook/list.asp?series=NRS5316\&item=4_4786\&ship=Thomas\%20Arbu thnot $\% 20[1]$

${ }^{60} \mathrm{http}: / /$ srwww.records.nsw.gov.au/ebook/list.asp?series=NRS5316\&item=4_4786\&ship=John\%20Knox

${ }^{61} \mathrm{http}$ ://srwww.records.nsw.gov.au/ebook/list.asp?series=NRS5316\&item=4_4786\&ship=Maria

${ }^{62} \mathrm{http}$ ///srwww.records.nsw.gov.au/ebook/list.asp?series=NRS5316\&item=4_4786\&ship=Tippoo\%20Saib
} 
Table 1 (continued). Orphan Girls' Demographics - Religious Identification and Ability to Read and/or Write

\begin{tabular}{|c|c|c|c|c|c|c|}
\hline & RC Both & RC Read & RC Neither & P Both & P Read & P Neither \\
\hline Earl Grey & 8 & 41 & 23 & 27 & 63 & 21 \\
\hline Inchinnan & 30 & 38 & 89 & 7 & 1 & 2 \\
\hline Digby & 65 & 58 & 80 & 16 & 5 & 5 \\
\hline Lady Peel & 38 & 53 & 64 & 8 & 2 & 1 \\
\hline \multicolumn{2}{|c|}{ William \& Mary } & 55 & 43 & 55 & 4 & \\
\hline Lismoyne & 45 & 46 & 63 & 6 & 6 & \\
\hline Panama & 18 & 33 & 99 & 3 & 3 & 1 \\
\hline \multicolumn{2}{|c|}{ Thomas Arbuthnot } & 72 & 48 & 70 & 4 & \\
\hline John Knox & 35 & 98 & 127 & 10 & 6 & 3 \\
\hline Maria & 59 & 69 & 112 & 1 & 2 & \\
\hline Tippoo Sai & 52 & 100 & 132 & 7 & 3 & 3 \\
\hline TOTALS & 476 & 629 & 910 & 93 & 95 & 37 \\
\hline
\end{tabular}

Table 2. National Origin in New South Wales by Census Year

\begin{tabular}{lll} 
& $1846^{63}$ & $1851^{64}$ \\
\hline Born in Colony & 54853 & 81391 \\
England & 47249 & 51122 \\
Wales & 541 & 558 \\
Ireland & 38421 & 38659 \\
Scotland & 10379 & 10907 \\
British Dominion & 1905 & 1955 \\
Foreign & 1186 & 2651
\end{tabular}

Table 3. Religious Adherents in New South Wales by Census Year

\begin{tabular}{lcccc} 
& $1846^{65}$ & $1851^{66}$ & $1856^{67}$ & $1861^{68}$ \\
\hline Anglican & 79810 & 93137 & 124505 & 159958 \\
Presbyterian & 16053 & 18156 & 25718 & 34692 \\
Wesleyan & 6338 & 10008 & 14952 & 23682 \\
Other Protestant & 3681 & 6472 & 6335 & 15274 \\
Roman Catholic & 47187 & 56899 & 73918 & 99193 \\
Jewish & 969 & 979 & 1430 & 1759 \\
Other & 496 & 1592 & 2424 & 16302
\end{tabular}

\footnotetext{
${ }^{63} \mathrm{http}: / /$ hccda.anu.edu.au/pages/NSW-1846-census-01_10

${ }^{64} \mathrm{http}: / /$ hccda.anu.edu.au/pages/NSW-1851-census-01_10

${ }^{65} \mathrm{http} / / / \mathrm{hccda} . \mathrm{anu} . \mathrm{edu} . \mathrm{au} / \mathrm{pages} / \mathrm{NSW}-1846$-census-01_8

${ }^{66} \mathrm{http}: / /$ hccda.anu.edu.au/pages/NSW-1851-census-01_8

${ }^{67} \mathrm{http}: / /$ hccda.anu.edu.au/pages/NSW-1861-census-02_15

${ }^{68}$ Ibid.
} 


\section{Bibliography}

Australian Broadcasting Corporation. ñThe Irish Famine Orphan Girls, ò Life Matters, August 26, 2010. Accessed March 28, 2014.

http://www.abc.net.au/radionational/programs/lifematters/the-irish-famineorphan-girls/3023330.

Australian Data Archive. ñHistorical Census and Colonial Data Archive Documents: New South Wales.òAccessed March 20, 2014.http://hccda.anu.edu.au/documents/.

Campbell, Michael. Irelandôs New Worlds: Immigrants, Politics, and Society in the United States and Australia, 1815-1922. Madison, Wisconsin. University of Wisconsin Press, 2008.

ñFemale Orphan Immigration,ò The Argus (Melbourne), January 24, 1850. Accessed March 24, 2014, http://nla.gov.au/nla.news-article4771328.

ñGlorious Prospects for South Australiaò. South Australian Register (Adelaide), February 26,1850, Accessed March 23, 2014, http://nla.gov.au/nla.news-article38450353.

Haines, Robin. ñThe Idle and the drunken wonâ do thereô Poverty, the New Poor Law and Nineteenth-century Government-assisted Emigration to Australia from the United Kingdom.ò Australian Historical Studies 108 (1997): 1-21.

Heyck, Thomas William. The Peoples of the British Isles: A New History From 1688 to 1870. Belmont, California: Wadsworth, 1992.

Irish Famine Memorial. ñFamine Orphan Girl Ships to Australia.ò Accessed March 28, 2014. http://www.irishfaminememorial.org/en/orphans/ships/.

ñrish Orphan Girlsò Freeman's Journal, January 9 1851, 7. Accessed March 15, 2014. http://nla.gov.au/nla.news-article115767770.

ñIrish Orphan Immigration, ò Geelong Advertiser, May 13 1850. Morning edition. Accessed March 15, 2014, http://nla.gov.au/nla.news-article93137443.

Jupp, James. The English in Australia. Cambridge: Cambridge University Press, 2004.

McClaughlin, Trevor. ñLost Children? Irish Famine Orphans in Australia.ò History Ireland 8 (2000), 30-34.

Moloney, Catriona and Helen Thompson. ñntroduction: đ́Border Traffic. ̂̂. Journal of Commonwealth and Postcolonial Studies 7.1 (2000): 3-14.

Nugent, Joseph. ñThe Human Snout: Pigs, Priests, and Peasants in the Parlour.ò Senses and Society 4:3 (2009): 283-301. 
Ođ̊Farrell, Patrick. The Irish in Australia: 1788 to the Present. Sydney: University of New South Wales Press Ltd., 2000.

Parkhill, Trevor. ñWith a little help from their friends: assisted emigration schemes 17001845.ò in To and From Ireland: Planned Migration Schemes c. 1600 - 2000, edited by Patrick J. Duffy, 57-78. Dublin: Geography Publications, 2004.

Proudfoot, Lindsay and Dianne Hall. Imperial Spaces: Placing the Irish and Scots in Colonial Australia. Manchester: Manchester University Press, 2011.

Ralls, Walter. ñThe Papal Aggression of 1850: A Study in Victorian Anti-Catholicism.ò Church History 43:2 (1974): 242-256.

Robins, Joseph A. ñ̃rish Orphan Emigration to Australia 1848-1850.òAn Irish Quarterly Review 57 (1968), 372-387.

Robinson, Portia. ñ am not for Marryingò in The Hatch and Brood of time: A Study of the First Generation of Native-born White Australians. Melbourne: Melbourne University Press, 1985: 65-96, 290-294.

Shaw, A.G.L. ñThe Beginning of Transportation to Australiaò in Convicts \& The Colonies: A Study of Penal Transportation from Great Britain \& Ireland to Australia \& other parts of the British Empire. Melbourne: Melbourne University Press, 1998): 38-57.

State Records of New South Wales. ñOnline' Microfilm of Shipping Lists.ò Accessed March 10 2014. http://www.records.nsw.gov.au/state-archives/guides-andfinding-aids/nrs-lists/nrs-5316/\#the-list-of-ships.

Ward, John M. Earl Grey and the Australian Colonies 1846 -1857: A Study of SelfGovernment and Self-interest. Melbourne: Melbourne University Press, 1958.

ñWorkhouse Emigration,ò The Sydney Morning Herald, August 19, 1850. Accessed April 3, 2014, http://nla.gov.au/nla.news-article12920366. 